\title{
Research on Development Mechanism and Strategy of Folk Art Industry in Northeast of China
}

\author{
Yi Tian ${ }^{1, a}$, Meng Meng ${ }^{1 b}$, Lyu Mei*1,c, Shifei Dong ${ }^{1}$ \\ ${ }^{1}$ Shenyang Jianzhu University Art and Design College Shenyang, China
}

\begin{abstract}
The folk art forms of northeast of China are rich and varied. They fully presents the cultural of northeast of China. However, with the transformation of China from a traditional agricultural society to a modern industrial society, people's production mode and life style have changed greatly, and The environment on which folk art depends has huge changed. Some folk art categories are on the verge of extinction, aging and some folk art are lost due to the death of the older generation of artists. The paper presents a study on how to effectively protect and inherit the folk art in northeast China from two follow aspects-- optimization of folk art form and platform construction. Through literature review, research framework, deductive content analysis, combination of quantitative analysis and qualitative analysis, research methods were proposed as guidelines for improved to protect and inherit the folk art:1) Research on contemporary cultural ecology of folk art. 2) Rational creative development of folk art industry in northeast of China. 3) Brand cultivation of folk art industry in northeast of China 4) Establishing and improving the standard trading platform and value evaluation system for folk art works 5) Relying on "Internet +" to establish the operation and communication platform for collectors, investors, folk artists and operators.
\end{abstract}

\section{Introduction}

There are many ethnic minorities living in northeast of China, and they have created a rich and colorful folk art culture together with the Han Nationality. The folk art in northeastern China originated from the masses of the people and it has profound historical connotation, which reflects information of the broad masses of the people's the production and life. The folk art forms of northeast of China are rich and varied, such as New Year paintings, Manchu paper-cutting, Manchu embroidery, Xiuyan jade carving, shadow puppetry and so on, which fully presents the cultural of northeast of China. However, with the transformation of China from a traditional agricultural society to a modern industrial society, people's production mode and life style have changed greatly, and The environment on which folk art depends has huge changed. Especially since the late 20th century, the aesthetic values under western modernism and postmodernism pushed Chinese folk art to the edge of art, and its inheritance declines or even disappears. Some folk art categories are on the verge of extinction, aging and some folk art are lost due to the death of the older generation of artists. However, it is noteworthy that some folk arts driven by the market economy have changed their ideas of inheritance and development, and moved towards art industrialization.

In the industrial development of folk art, at first we should change our thinking and establish the idea that folk art is not only a cultural art treasure, but also a potential resource that can be transformed into commodities. The industrial development of folk art is the change process of transforming some folk art forms, from which used to be privately taught, apprenticeship and free enterprise forms into artistic commodities and operate according to market rules, and reaching a considerable scale and creating profits. The industrial development of folk art is also standardized and creative based on the traditional attributes of folk art. Though modern market theory and economic theory make folk art more suitable for the development direction of modern market economy and become the driving force for today's social and economic development.

\section{How to be self-optimization of folk art industry in Northeast China reconstruction of the value of folk artSelecting a Template}

\subsection{Research on contemporary cultural ecology of folk art}

The decline of folk art does not mean the death of folk art, but the nature reconstruction of folk art. Li Yanzu[1] believed that there are two forms of folk art, one is the original state folk art, the other is the market state folk art. In essence, the market folk art state is no longer the traditional folk art, but the product of cultural industry. This kind of market mode is the most profound transformation of traditional folk art caused by social and

\footnotetext{
a465474772@qq.com

b13526103@qq.com

${ }^{*}$ Corresponding author: Lynmei@sjzu.edu.cn
} 
cultural changes in the 20th century. By investigating the traditional folk culture in the west, Lili Fang[2] proves the fact that the folk art is changing and being reconstructed in the social transformation period. As a form of artistic expression, many folk rituals, songs and dances and handicrafts in the west of China not only still exist, but also have been developed, and their art forms are more aesthetic and professional. She believes that the reconstruction of traditional folk culture comes from various forces, which contributes to the combination of tourism and folk art, the marginalization of traditional crafts and the rise of new folk art. Some scholars study the inheritance and development of folk art from the angle of protecting the cultural ecological environment of folk art. Lusheng Pan [3] believed that only under the context of living certain environment of the people, the connotation of folk culture could be deeply discussed. So the lost cultural tradition and the ecological environment of national folk culture should be protected.

To coordinate relationship of elements of folk art of cultural ecology in t order for the sustainable development of folk art. Shixian Zhang[4]conducted field investigations on four villages near central of Shandong. He set from the perspective of art folklore, taking villages as units and investigate the reconstruction and revival of rural traditions of China in the past 20 years. By local family and village inheritance of collective memory, folk psychology and behavior and so on, to discuss inherent law of formation, maintaining, decay of folk art under the context of traditional village. To reformulate the villagers art 's characteristics and meaning in the context of village, provides the study of the art of villagers "family - village" the new mode of transmission system and its contemporary significance.

Taking the paper cutting of Manchu in northeast of China as an example, it should be self-optimization and conform to the development direction of cultural industry. The first step is to study and protect the contemporary development background environment of the paper cutting of Manchu.

To understand the Manchu cut paper cutting art, people should set from the origin of the Manchu, ethnic composition and the change of history, at the same time the Manchu cut paper's development inseparable from $t$ Manchu art and the formation of the Manchu nationality handicraft. To explore Manchu cut paper's traditional form, its influence of modern culture and crafts ethnic group is the beginning of the study of paper cutting art heritage and development of Manchu. The Manchu folk paper-cut art is spread and inherited from generation to generation in Beizhen city, Linghai City, Fuxin City and Yixian city in the Yiwu Lvshan area of Liaoning province. In many urban and rural areas, a large number of women participate in paper-cutting activities and produce a lot of skilled artists, and formed the ancestral inheritance pedigree. Through sorting out and analyzing the inventory of intangible cultural heritage database in Liaoning Province, the formation of Manchu art can be traced and study. The existing categories mainly include: Manchu music, Manchu dance, Manchu folk art and Manchu traditional handicraft and so on. Manchu folk art includes: Manchu folk paper cutting, Yiwu Lvshan Manchu paper cutting, Xiuyan Yiwu Lvshan Manchu autonomous county paper cutting. Chinese paper cutting has a long history. Manchu paper cutting as a member of Manchu paper cutting is the precious wealth of Chinese art. Each ethnic group and region has its own unique style and subject of paper-cut art form. In Kanto, due to the influence of special regional environment and folk customs, craftsmen tried to make paper cuttings with birch bark, fish skin, bud leaves, other animal and plant materials. Manchu traditional cut paper cutting art form is also reflected in People's Daily life, for instance stick on the wooden window from the "window", posted on woodwork "hang sticker" or "hang money", the shaman ritual use "Gonghua", "Xihua" for the marriage customs, "Bed Flowers" beautify the environment, "Ceiling Flowers " to used for embroidery pattern of shoes, etc. Auspicious Manchu paper cutting art has deep into the common People's daily life and aesthetic emotion. Meanwhile Manchu's spirit and the enthusiasm in productive labor from beginning to end throughout the Manchu cut paper in the whole process of the creation.

Until now, the traditional customs of the Manchu have gradually changed or disappeared due to modern life' change. The traditional themes and forms of Manchu paper-cuts are also changed under the influence of the change of the cultural and ecological environment. The function of paper-cutting for sacrificial I has been no longer exist. The situation that due to the lack of paper materials, seeking bark, fish skin and corn as alternative is gone. on the contrary, the cost of such natural materials like bark, fish skin is more expensive. Therefore, when Manchu paper cutting reconstruct its artistic value, it should be considered from the current cultural and cultural ecological background. First of all, it is necessary to evaluate whether the cultural ecological environment under the cultural phenomenon has restoration value. Secondly, whether cultural phenomena should be adapted to the current change of cultural ecological environment. For example, before many shaman paper-cuts were created around the needs of shaman sacrifice activities. With the development of social science and technology, Shamanism gradually withdrew from the stage of history, but thought "the integration of man and nature", "the hope of a better life", "good luck still spread so far. Therefore, with the current change of ecological environment background, the main function of Shaman paper-cut has changed from practical and functional folk use to decorative symbolic significance.

\subsection{A Rational creative development of folk art industry in northeast of China}

In terms of the industrialization of folk art in northern China, there are different problems about decontextualized from the local context. The industrial development of folk art is, first of all, to protect itself. Secondly it adapts to the environment and discards and insist itself during the development. Predatory development means, which sacrifices the natural environment and national culture ecology environment for pursuit of economic benefits, makes the industrialization 
of folk art deviated from the healthy development track.

Table1. Comparison of folk culture of National Intangible Cultural Heritage in Liaoning Province

\begin{tabular}{|c|c|c|c|}
\hline \multirow{2}{*}{$\begin{array}{l}\text { The national } \\
\text { intangible cultural } \\
\text { heritage of Liaoning } \\
\text { Province }\end{array}$} & \multicolumn{3}{|r|}{ Table Column Head } \\
\hline & Recent masterpieces & $\begin{array}{l}\text { Inheritance } \\
\text { people }\end{array}$ & Characteristic \\
\hline $\begin{array}{l}\text { Yiwulv Mountain } \\
\text { Manchu paper-cut }\end{array}$ & $\begin{array}{l}\text { "Mountain God", "Fox } \\
\text { God", "Snake God", } \\
\text { "Willow Mother", "Nine } \\
\text { milk Mother }\end{array}$ & $\begin{array}{l}\text { Guizhi } \\
\text { Hou,Fengyu } \\
\text { n Ma }\end{array}$ & $\begin{array}{l}\text { The main performance contents are the primitive worship of nature god, } \\
\text { ancestor god, reproduction worship and manchu custom. }\end{array}$ \\
\hline $\begin{array}{l}\text { Fuxin Agate } \\
\text { Sculpture }\end{array}$ & "Solved" & Hongbing $\mathrm{Li}$ & $\begin{array}{l}\text { It is good at simple living, and uses the techniques of round carving, relief } \\
\text { carving, hollow-out carving. }\end{array}$ \\
\hline Xiuyan Jade Carving & "September circle reunion" & Hongcai Li & $\begin{array}{l}\text { Most of Xiuyan jade carving crafts is small products. The theme mainly, live, } \\
\text { people, flowers, birds, animals, beast. }\end{array}$ \\
\hline $\begin{array}{l}\text { Xinbin Manchu } \\
\text { Paper-cut }\end{array}$ & "The Shaman Dance" & $\begin{array}{l}\text { Shumei } \\
\text { Guan }\end{array}$ & $\begin{array}{l}\text { It main performance contents Manchu shaman culture and manchu folk festival } \\
\text { activities as the, including Manchu religious belief, folklore, mythology, folk } \\
\text { customs, life, flowers, birds, grass and insects, etc. }\end{array}$ \\
\hline $\begin{array}{l}\text { Lingyuan Shadow } \\
\text { Play }\end{array}$ & $\begin{array}{l}\text { "Double Happiness", " The } \\
\text { Legend of the White } \\
\text { Snake" }\end{array}$ & $\begin{array}{l}\text { Zhensheng } \\
\mathrm{Yu}\end{array}$ & $\begin{array}{l}\text { The shadow puppetry is made of cowhide and donkey leather for its rigidity and } \\
\text { transparency, so it is also called "the shadow puppetry" }\end{array}$ \\
\hline $\begin{array}{l}\text { Xiuyan Northeast } \\
\text { Drum }\end{array}$ & "The Bite Password" & $\begin{array}{l}\text { Jingzhou } \\
\text { Sun, Guian } \\
\mathrm{Fu}\end{array}$ & $\begin{array}{l}\text { It belong to the fengdiao, it inherited fengdiao's the essence of the big drum, } \\
\text { and base on the xiuyan region characteristics it have developed innovation. }\end{array}$ \\
\hline $\begin{array}{l}\text { Fuzhou Shadow } \\
\text { Puppetry (Liao } \\
\text { Opera) }\end{array}$ & $\begin{array}{l}\text { "Ten Thousand Treasure } \\
\text { Array", "Swarm of fairy } \\
\text { Array" }\end{array}$ & $\begin{array}{l}\text { Guochao } \\
\text { Song }\end{array}$ & $\begin{array}{l}\text { It is unique singing style, directly molded character image, comprehensive and } \\
\text { diverse artistic forms. It is full of interest and entertainment, which has strong } \\
\text { identity among the people. }\end{array}$ \\
\hline
\end{tabular}

That is the why so many scholars against the commercialization of folk art. The industrial development of folk art is essentially the result of its inner and external forces. In the history, folk art has produced huge economic benefits and appeared the germination of commercialization. The glorious period of many folk art was also the period when it created great economic benefits. Through the vicissitudes of time, the folk art can still show its true beauty- that is strong vitality. It is impossible folk art develops in the contemporary, either by letting it drift with the tide or by roughly protecting the frame. Only when it comes into contact with modern life, finds its proper place in modern life, folk art realizes its value, it is inherited reasonably.

In fact, the contradiction between folk art development and protection is not coordination. So the key to harmonize is to see the developer's approach to develop. The industrialization and commercialization of folk art is the only way for its development and inheritance. Not only can the folk art bring economic benefits, the economic benefits can promote the development of the folk art, but also the correct guidance can make it adapt to social development and better inherit. Folk art carries out cultural and artistic innovation by means of modern science and technology, no longer sticking to traditional themes and techniques, but digging out new themes and creating more classic works, so as to inherit and continue the folk culture of the nation. The rational development of folk art industry is neither a distortion driven by one-sided economic interests, nor a blind inheritance. But it is a kind of development with keep and abandon, a re-creation integrating modern consciousness into national tradition, and also a really and correctable response to the culture changing.

In the commercialization of shaman paper-cut innovation development, in fact, some cultural and creative companies have made reasonable development, such as hanging paper-cut for the Manchu shaman worship ceremony, when worship hanging on the ancestor board, shrine, above the Shrine. In the later, it was hung on the top of the door for decoration during the Spring Festival in countryside. In modern Manchu paper-cut creative development, the paper-cutting are made to be a signs of the design combined with the meaning of good luck. It is made into hanging decoration. This kind of artistic thinking of national historical view makes the traditional paper-cut add new wings and reach the high point of literary and artistic creation. The inheritance people especially emphasize the sublimation of the object's shape in the traditional Manchu art, which also makes the creators of the Manchu art of cutting and carving paper pay more attention to the pursuit of realistic modeling style. The new idea and the new techniques change papercutting expression form, meanwhile to give the traditional art a new modern interpretation. Narrowing the distance between artistic works and contemporary appreciation.

\subsection{Brand cultivation of folk art industry in northeast of China}

Due to the spread's passivity and the sales mode' simplicity of folk art make the folk art products lack enough attraction. One of the important ways to solve this problem is to cultivate representative and influential brands for folk art. Huilin Hu believes that "the national cultural products can form a brand should firstly fully and perfectly express a nation's understanding and grasp of the world, its feeling and understanding of life, its pursuit and yearning for truth, goodness and beauty, and its persistence and transcendence of reality." Brand is the mark used on the commodity, is a kind of intangible asset, has invisible value. Is the intangible assets of the enterprise, with identification function, represents the production or management of the enterprise's quality 
reputation and corporate reputation, image, represents the product and the comprehensive level of the enterprise, the enterprise can use the brand advantage to show their ability to develop the market. Although liaoning's traditional folk handicraft resources are rich, there are only a few influential traditional handicraft brands. It is urgent to select a batch of traditional handicrafts products to develop brand that not only contain regional cultural elements, but also meet contemporary daily needs, aesthetic value and environmental protection requirements. At the same time, they have industrial development commercial potential. Relying on the resource database of Liaoning Province's intangible cultural heritage list and traditional craft list, to establish the pillar industry brand with prominent regional cultural characteristics, skills and good aesthetic taste traditional handicraft in each city. Such as the existing Xiuyan jade carving, Fuxin agate, Manchu embroidery and other traditional handicrafts have the potential for industrial development.

\section{Constructing market and platform of folk art industry in northern China}

To develop the art industry market, besides optimizing the folk art itself, it is also crucial to establish a standardized market operation platform. In order to make the folk art market develop continuously, the establishment of a standardized market operation platform is undoubtedly the focus of the whole mechanism. There are following two aspects of platform.

\subsection{Establishing and improving the standard trading platform and value evaluation system for folk art works}

Under the impact of the worldwide financial crisis, the rapid decline of assets makes more people begin to pay attention to the value preservation of art work. With the gradual accumulation of capital, the trend of asset and capitalization of the art market has emerged, becoming a new direction of the folk art market and constantly entering the timetable of local governments. The blocked capitalization process of art property is an important obstacle to the large-scale development of the current folk art market. The important functions of art supervision and management institutions include solving the appraisal problem of folk art assets and breaking through the bottleneck of folk art assets capitalization. Department in charge of local cultural needs and related financial departments on the issue of cohesion, and reference to other art appraisal method has been set up, such as financial department has established jewelry appraisal agency and make assessment method, strive to make part of the folk art assets appraisal into local fiscal system, achieving capitalization of folk art as soon as possible, in order that enlarge the folk art industry scale, on a higher platform to show value has an important value.

\subsection{Relying on "Internet + " to establish the operation and communication platform for collectors, investors, folk artists and operators}

The art market has introduced "Internet thinking" and accelerated the development of platform. Under high speed the Internet development, after traditional galleries (primary market) and auction companies (secondary market), a new trading platform is born. The Internet transcends the limitations of time, space, national, boundaries, regions, traditional channels, people, scale and quantity. It also takes into account the functions of galleries, auction houses and information publishing platforms, and provides audiences with 24hours services, providing a brand new platform for art trading and communication. The rules of this platform are internetbased, that is, online terminals, free trading, and big data system management, forming a new set of assessment and pricing mechanism, and the "mouse-over" mechanism, which makes the whole transaction process more transparent and fair.

Today's art websites can be generally divided into "information platform", "trading platform", "collaboration platform", "publicity and promotion platform", "tool platform" and so on. The emergence of art websites does not make the traditional way of art communication and trade dead, instead, more and more artists and audiences can break the obstacle, receive information and communicate as soon as possible. Thus both sides can get more opportunities though the platform. Art platforms relying on "Internet + " adopt overall evolution and integration strategies. The integration is not only the combine of media technology and communication system, but also the combine of cultural forms. For example, many folk art forms are sold on Taobao after being branded and innovated, and the sales volume is very good, which is to take advantage of the people-oriented and life-oriented nature of Taobao platform. Meanwhile, At present, many folk artists create works of art on the live broadcast platform and show their exquisite skills to people. And then people have more understanding of this kind of folk art, it can stimulate consumption.

\section{Conclusion}

To sum up, the folk art has gone through the vicissitudes of time and keeping changing under any social, economic and cultural ecology, so as to show the really beauty. Folk art industry development, not only can realize the survival of folk art itself in the modern society, but also more important is the spiritual wealth on the folk art to inheritance. Therefore, to innovate and develop the Liaoning traditional handicraft industry, it is very important to apply well capital element, technology element, policy element, also it should focus on cultural factor, knowledge factor, cultivate and establish the core brand, develop its industry leading, boost the local economy. 


\section{Acknowledgment}

This research was support by the Shenyang Association of Social Sciences (Grant No. SYSK2020-09-10), We also would like to express our sincere gratitude to the editor anonymous reviewers for their valuable comments, which have greatly improved this paper.

Research on the Development Mechanism and Strategy of Shenyang folk Traditional Culture and art IndustrySYSK2020-09-10. (Shenyang social science project approved)

\section{References}

1. Yanzu Li , "The history and culture of product design for the Beauty of Creation" Beijing:Renmin University of China Press,2000, pp. 74-78.

2. Lili Fang, "From Heritage to Resources -- Research Report on Humanistic Resources in Western China" Beijing:Xueyuan Press2010.

3. Jialu Tang and Lusheng Pan, "Introduction to Chinese Folk Art" Heilongjiang: Heilongjiang Pres2006, pp. 59-62.

4. Lusheng Pan, "The cultural ecology of folk art" Beijing: Qinghua University Pres2011, pp. 29-31.

5. Shishan Zhang, "Chinese art folklore"Qingdao Shandong People's Publishing House2008.

6. Suo Zhang, "Research on the industrial development mechanism and Path of China's current folk art" Degree-Granting University, Shanghai University,2015.

7. Liming Bai, "Ewenki national traditional society and culture" Beijing: Science Pres 2010.

8. Yuguang Fu. "Shaman Theory". Liaoning: People's Publishing House2012.

9. Feuerbach, Ludwig, "The essence of Christianity “ N.Y.: Dover, 2008

10. Hongfu Li . "Shaman Plastic Art "Beijing: National Publishing House,2006. 